\title{
Upaya Meningkatkan Kemampuan Penalaran Matematis Siswa melalui Model Problem Based Learning pada Materi Aritmetika Sosial di Kelas VII-1 SMPN 176 Jakarta
}

\author{
Nurul Abidah", a), Lukman El Hakim², b), Dwi Antari Wijayanti ${ }^{3, c)}$ \\ ${ }^{123}$ Universitas Negeri Jakarta, Rawamangun, Jakarta Timur
}

Email: a)nurulabidah.na@gmail.com, b)lukman111985@gmail.com, ${ }^{c}$ tarie_ku@yahoo.co.id

\begin{abstract}
Abstrak
Penelitian ini dilakukan untuk meningkatkan kemampuan penalaran matematis siswa melalui model Problem Based Learning. Metode penelitian ini adalah Penelitian Tindakan Kelas (PTK). Penelitian ini dilakukan selama tiga siklus dan dilakukan kepada 36 siswa dengan memilih 6 siswa yang digunakan sebagai subjek penelitian. Analisis data dilakukan dengan mendeskripsikan data kuantitatif dan kualitatif yang diperoleh selama proses tindakan pembelajaran. Penelitian ini menunjukkan hasil kemampuan penalaran matematis siswa dapat meningkat melalui penerapan model Problem Based Learning. Peningkatan terlihat dari peningkatan setiap Subjek Penelitian (SP), nilai rata-rata tes akhir kemampuan penalaran matematis siswa yang masuk dalam kategori sangat baik, dan jumlah siswa yang telah dapat meraih kategori baik. Nilai rata-rata tes akhir kemampuan penalaran matematis siswa kelas VII-1 SMPN 176 pada siklus 1 adalah 68,17, meningkat pada siklus 2 menjadi 78,59 dan meningkat kembali pada siklus 3 menjadi 84,95 yang telah masuk kategori sangat baik. Berdasarkan data yang diperoleh, jumlah siswa yang mendapatkan nilai tes akhir siklus melampaui kategori baik mengalami peningkatan. Pencapaian peningkatan jumlah siswa tersebut diraih dengan rata-rata yang telah meraih kategori baik pada siklus 1 yaitu sebanyak 25\% siswa dan siklus 2 sebanyak 58\% siswa serta kategori sangat baik pada siklus 3 sebanyak $75 \%$ siswa.
\end{abstract}

Kata kunci: kemampuan penalaran matematis, model Problem Based Learning, materi aritmetika sosial.

\section{PENDAHULUAN}

Perkembangan pembelajaran matematika di sekolah semakin pesat. Hal ini tidak sejalan dengan peningkatan kemampuan siswa dalam pembelajaran matematika. Perkembangan pembelajaran matematika yang tidak sejalan dengan peningkatan kemampuan siswa ini, ditunjukkan dengan kemampuan siswa dalam menemukan hubungan, pola dan sifat-sifat dalam mempelajari matematika yang masih kurang. Padahal dengan mereka mampu melakukan hal tersebut, mereka dapat memahami permasalahan matematika dengan melihat bukti-bukti dari setiap penyelesaian matematika dengan baik. Kemampuan tersebut disebut dengan kemampuan penalaran matematis. Kemampuan ini juga termasuk tujuan yang penting untuk siswa miliki dari pembelajaran matematika yang siswa dapatkan saat kegiatan belajar mengajar di sekolah yang tercantum dalam standar isi yaitu siswa mampu menggunakan penalaran pada pola dan sifat, melakukan manipulasi matematika dalam membuat generalisasi, menyusun bukti, atau menjelaskan gagasan dan pernyataan matematika (Wardhani, 2008). Hal ini sejalan dengan Turmudi (Turmudi, 2008) bahwa kemampuan penalaran matematis merupakan suatu kebiasaan otak seperti halnya kebiasaan lain yang harus dikembangkan secara konsisten menggunakan berbagai macam konteks, mengenal penalaran dan pembuktian merupakan aspek-aspek fundamental dalam matematika.

Kemampuan penalaran matematis juga merupakan standar dalam pembelajaran matematika yang ditetapkan National Council of Teacher of Mathematics (NCTM) (NCTM, 2000). Lima kemampuan dasar dalam pembelajaran matematika tersebut juga meliputi pemahaman konsep matematis (Conceptual Understanding mathematics), 
pemecahan masalah (problem solving), penalaran dan pembuktian (reasoning and proof) dan komunikasi (communication). Hal ini juga didukung dengan hasil capaian ratarata peserta Indonesia pada TIMSS 2011 (Rosnawati, 2013) bahwa rata-rata persentase yang paling rendah yang dicapai oleh siswa Indonesia adalah dalam domain kognitif pada level penalaran yaitu $17 \%$. Indikator kemampuan penalaran matematis siswa oleh Jihad dan Haris diuraikan bahwa indikator siswa memiliki kemampuan dalam penalaran adalah mampu: (1) mengajukan dugaan, (2) melakukan manipulasi matematika, (3) menarik kesimpulan, menyusun bukti, memberikan alasan atau bukti terhadap kebenaran solusi, (4) menarik kesimpulan dari pernyataan, (5) memeriksa kesahihan suatu argumen, dan (6) menemukan pola atau sifat dari gejala matematis untuk membuat generalisasi.

Berdasarkan hasil wawancara, guru pengampu mata pelajaran matematika menyatakan bahwa kemampuan penalaran matematis siswa kelas VII-1 SMPN 176 Jakarta masih rendah.Pembelajaran yang dapat menggali dan mengembangkan kemampuan penalaran matematis adalah pembelajaran matematika dengan model Problem Based Learning. Pada pembelajaran matematika, (Padmavathy dan Mareesh, 2013) "Problem Based Learning method of teaching is more effective for teaching mathematics and also Problem Based Learning instructional strategy had an effect on content knowledge which provides greater opportunities for the learners to learn a content with more involvement and increase the students active participation, motivation and interest among the learners". Keterampilan berpikir seperti penalaran matematis dapat dikembangkan dalam memecahkan masalah yang membutuhkan penalaran dalam penyelesaiannya dengan menggunakan model ini (Simatupang dan Surya, 2017). Pembelajaran dengan model ini melibatkan siswa aktif dalam proses belajar yaitu siswa dituntut untuk aktif dalam berpikir, bernalar, berkomunikasi, mencari data dan mengolah data, dan akhirnya menyimpulkan. Hal ini senada dengan pernyataan bahwa Problem Based Learning digunakan untuk membantu siswa mengembangkan keterampilan berpikir, keterampilan menyelesaikan masalah dan keterampilan intelektualnya, melalui pengorganisasian pelajaran di seputar situasi-situasi kehidupan nyata (Arends, 2012). Selain itu, model yang sesuai dan mendukung siswa untuk dapat melakukan penalaran matematis dalam aritmetika sosial adalah model Problem Based Learning. Hal tersebut sesuai karena materi aritmetika sosial adalah materi yang membahas dan menampilkan berbagai macam permasalahan situasi-situasi kehidupan nyata untuk mendukung siswa dalam meningkatkan kemampuan penalaran matematis.

Tujuan dilakukannya penelitian ini, yaitu untuk mengetahui bagaimana penerapan dan apakah model pembelajaran Problem Based Learning pada materi aritmetika sosial dapat meningkatkan kemampuan penalaran matematis siswa di kelas VII-1 SMPN 176 Jakarta. Hipotesis tindakan dibuat sebelum penelitian ini dilakukan, hal ini digunakan sebagai dugaan awal pada penelitian ini yaitu sebagai berikut: "Penerapan model Problem Based Learning pada materi Aritmetika Sosial diharapkan dapat meningkatkan kemampuan penalaran matematis siswa kelas VII-1 di SMPN 176 Jakarta". Penelitian yang dilakukan oleh Yanto Permana dan Utari Sumarmo pada tahun 2007 dengan judul "Mengembangkan Kemampuan Penalaran dan Koneksi Matematik Siswa SMA Melalui Pembelajaran Berbasis Masalah" ini adalah penelitian kuantitatif eksperimen dan dilakukan di tingkat SMA. Kesimpulan dalam penelitian tersebut adalah kemampuan penalaran matematis siswa yang memperoleh pembelajaran berbasis masalah lebih baik dari pada penalaran matematis siswa melalui pembelajaran biasa. Penelitian ini hanya mengukur kemampuan penalaran matematis dan dilakukan dengan pendekatan kualitatif yaitu PTK sedangkan penelitian tersebut adalah penelitian kuantitatif eksperimen. Penelitian lain digunakan yaitu penelitian Retno Maristin yang berjudul "Kemampuan Penalaran dan Koneksi Matematis dalam Pembelajaran Matematika dengan Problem solving". Penelitian ini menggunakan pendekatan kualitatif yaitu PTK. Penelitian ini menunjukkan bahwa kemampuan penalaran dan kemampuan koneksi matematis dalam pembelajaran dengan Problem Solving semakin meningkat dan kualitas pembelajaran semakin baik. Penelitian tersebut dilakukan pada mahasiswa, perbedaannya dengan penelitian ini dilakukan pada siswa SMP. 


\section{METODE}

Penelitian ini menggunakan pendekatan penelitian kualitatif. Metode yang digunakan dalam penelitian ini adalah Penelitian Tindakan Kelas (PTK). Suryanto mendefinisikan PTK sebagai suatu bentuk penelitian yang bersifat reflektif dengan melakukan tindakan-tindakan tertentu agar dapat memperbaiki dan/atau meningkatkan praktik-praktik pembelajaran di kelas secara profesional (Laksono dan Eko, 2018). PTK dilakukan bersiklus (Martiyono, 2017), minimal 2 (dua siklus) yang setiap siklusnya mencakup kegiatan: perencanaan tindakan (planning), pelaksanaan tindakan (acting), pengamatan (observing) dan refleksi (reflecting). Sumber data yang digunakan dalam penelitian ini adalah 36 orang siswa kelas VII-1 SMPN 176 Jakarta. Teknik pengumpulan data dilakukan dengan mengumpulkan data yang dibutuhkan dalam proses penelitian ini. Participant observer mendapatkan data untuk melakukan refleksi tindakan yang telah dilakukan guru sebagai dasar perbaikan tindakan untuk siklus berikutnya. Jenis data yang digunakan, yaitu data kuantitatif dan kualitatif. Data kuantitatif yaitu hasil tes awal kemampuan awal siswa yang dilakukan pada penelitian pendahuluan dan hasil perolehan nilai tes akhir kemampuan penalaran akhir setiap siklus. Penelitian ini menggunakan ketegori penalaran matematis yang diambil dari Hidayat dan Astuti pada tabel 1. Data kualitatif yaitu data hasil hasil observasi, dokumentasi foto, hasil wawancara, dan catatan lapangan pada setiap siklus.

TABEL 1. Kategori Kemampuan Penalaran Matematis

\begin{tabular}{|c|c|}
\hline Kategori & Nilai \\
\hline Sangat Baik & $81-100$ \\
\hline Baik & $66-80$ \\
\hline Cukup & $56-65$ \\
\hline Kurang & $40-55$ \\
\hline Sangat Kurang & $\leq 39$ \\
\hline
\end{tabular}

Validasi data dilakukan untuk memastikan kevalidan data yang diperoleh selama penelitian dengan menggunakan sistem triangulasi data. Triangulasi adalah membandingkan informasi sumber data yang satu dengan yang lain di dalam situasi yang sama. Perbandingan dilakukan setelah data terkumpul tiap siklus, maka proses selanjutnya adalah menganalisis data-data tersebut. Analisis data kuantitatif, yaitu dilihat dari nilainilai tes akhir siklus siswa, di mana mendeskripsikan data dari sisi rata-rata atau yang lain. Analisis data kualitatif adalah segala proses mencari dan menyusun dengan sistematis data-data yang telah dikumpulkan untuk mendapatkan pengetahuan dan pengalaman dari data tersebut, lalu disusun sedemikian rupa untuk mendapat benang merah/ kesimpulannya untuk selanjutnya agar dapat dikomunikasikan. Kriteria yang menjadi keberhasilan dalam penelitian ini sebagai berikut:

1. Nilai rata-rata kemampuan penalaran matematis siswa mengalami peningkatan pada setiap siklus khususnya keenam subjek penelitian.

2. Rata-rata nilai kemampuan penalaran matematis siswa dalam kategori "Sangat Baik" yaitu minimal dapat mencapai 81.

3. Hasil tes akhir siklus dikatakan meningkat jika rata-rata hasil tes akhir siklus mencapai kategori "Baik", yaitu $75 \%$ dari jumlah siswa mendapatkan nilai minimal lebih dari atau sama dengan 76.

\section{HASIL DAN PEMBAHASAN}

\section{Hasil}

Penelitian ini dilakukan selama tiga siklus yang setiap siklusnya mencakup kegiatan perencanaan tindakan, pelaksanaan tindakan yaitu pertemuan pembelajaran, tes akhir siklus, wawancara, yang selanjutnya dianalisis dan direfleksi sebagai upaya perbaikan tindakan pada siklus selanjutnya. Berdasarkan pembelajaran siklus 1 , secara keseluruhan menunjukkan bahwa siswa di kelas cukup aktif dan masih dalam tahap adaptasi dalam melakukan pembelajaran matematika secara kelompok, mengingat ini adalah perubahan pertama kali yang dilakukan oleh guru untuk menerapkan pembelajaran matematika secara berkelompok. Namun ada juga terlihat siswa yang kurang antusias atau terpecah fokusnya karena tidak memperhatikan saat proses pembelajaran berlangsung. Terlihat siswa mulai terlihat dapat beradaptasi dalam 
melakukan pembelajaran secara berkelompok yang ditandai proses perpindahan tempat duduk, melakukan diskusi dan bertukar pikiran dalam kelompok yang mulai dapat terlaksana dengan cukup baik. SP 1, SP 5 dan SP 6 terlihat antusias dalam proses diskusi. SP 3 terlihat berusaha untuk aktif berdiskusi walaupun SP 2 yang berkemampuan tinggi terlihat ambisius untuk mengerjakannya secara individu tanpa terjadi diskusi yang aktif, selain itu SP 3 juga tidak malu-malu untuk bertanya kepada guru apabila ada yang belum dimengerti. SP 4 juga terlihat masih kurang aktif dalam melakukan diskusi kelompok.

Berdasarkan pembelajaran siklus 2, secara keseluruhan siswa terlihat sudah dapat melakukan pengkondisian dan pengelompokan kelompok dengan lebih efektif sehingga alokasi waktu dapat terjadi dengan baik dan tidak terlalu membuang waktu. Selain itu guru sudah tidak begitu mendominasi dalam proses pembelajaran dan guru terlihat mampu memberikan pertanyaan-pertanyaan yang membangkitkan kemampuan penalaran matematis siswa. Saat jalannya diskusi, SP 1 terlihat fokus dan mendominasi dalam memimpin diskusi dan SP 6 terlihat dapat bekerja sama dengan baik dalam kelompok, merespons pertanyaan guru dan aktif di kelas saat proses pembelajaran berlangsung sehingga terjadi diskusi timbal balik antara guru dan siswa. Selain itu, SP 6 di kelompok aktif dengan menyumbangkan ide dan memberikan pendapat mengenai penyelesaian LAS yang dilakukan secara berkelompok. Sedangkan SP 2 dan SP 3 sama-sama aktif dalam diskusi tetapi SP 3 butuh konsentrasi lebih dalam memahami materi dan SP 2 terlihat lebih memimpin jalannya diskusi dalam kelompoknya. SP 2 dan SP 4 ketika sudah mengerti pengarahan yang diberikan oleh guru mereka langsung mencoba menyelesaikan LAS. Hal ini terlihat dari peningkatan yang dialami SP 2. Peningkatan ini terjadi karena adanya peningkatan pada indikator 3 tes akhir siklus 2 yaitu menarik kesimpulan, menyusun bukti, memberikan alasan atau bukti terhadap kebenaran solusi. SP 2 terlihat peningkatannya selain sudah dapat menyusun bukti dengan baik, peningkatan yang terjadi yaitu SP 2 sudah dapat menarik kesimpulan dengan baik dan benar berdasarkan bukti yang sudah ia paparkan. Hal ini dapat dilihat pada gambar berikut.

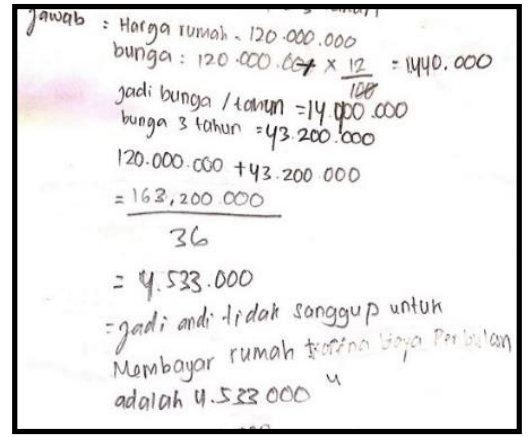

GAMBAR 1. Jawaban SP2 Indikator 3 Soal Nomor 1 pada Siklus 2

Sedangkan SP 5 terlihat berdiskusi aktif dengan SP 4 mendiskusikan permasalahan dalam LAS dan SP 5 tetap memperhatikan arahan dari guru meskipun tidak begitu terlibat dalam diskusi. Proses pembelajaran pada siklus 2 hampir sebagian besar keterlaksanaannya sudah berjalan dengan baik dari siklus sebelumnya walaupun ada kendala yang terjadi namun dapat diselesaikan oleh inisiatif dan kesigapan guru dalam kelas. Suasana kelas sudah lebih baik dari siklus lalu hal ini ditunjukkan dengan pengarahan pada siswa yang sudah dilakukan secara cukup kondusif. Selain itu, siswa juga sudah terlihat cukup terbiasa dan sudah cukup mengetahui serta memahami pengarahan dari guru.

Hasil perolehan nilai rata-rata tes akhir siklus 3 yaitu 84,95 berhasil mencapai kategori sangat baik yaitu minimal meraih rata-rata 81 . Selain itu, pada siklus 3 pencapaian berhasil diraih 27 siswa atau sebesar $75 \%$ dari total keseluruhan siswa telah berhasil mencapai kategori baik dengan memperoleh nilai minimal lebih dari atau sama 76 berdasarkan kategori penalaran matematis siswa. Berdasarkan pembelajaran siklus 3 , aktivitas pada siklus ini terlihat lebih baik dari siklus sebelum-sebelumnya dengan ditunjukkan aktivitas guru yang menerapkan hasil refleksi siklus lalu dengan baik. Hal ini terlihat secara keseluruhan menunjukkan bahwa siswa di kelas aktif dan sudah dapat melakukan adaptasi dengan baik terhadap setiap tahap pembelajaran. 


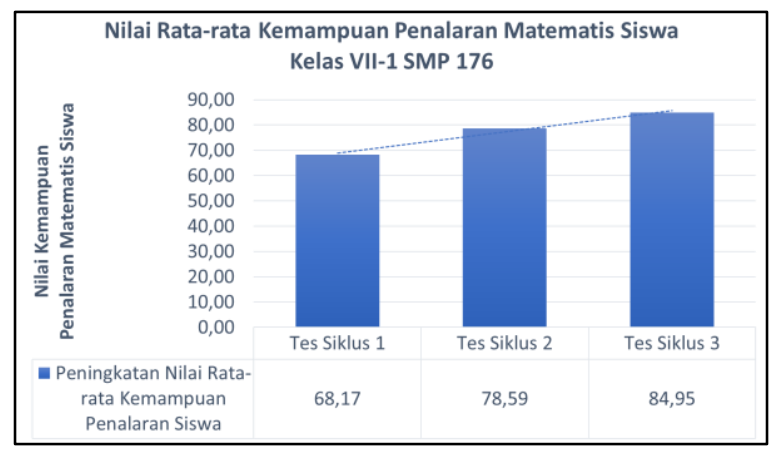

GAMBAR 2. Peningkatan Nilai Rata-rata

Kemampuan Penalaran Matematis Siswa Kelas VII-1

Guru juga terlihat sudah dapat melakukan tahap-tahap pembelajaran dengan baik terutama kemampuan guru dalam menggali dan mengarahkan pengetahuan siswa serta memancing siswa untuk memaparkan strategi dalam mengambil keputusan dalam bernalar terhadap permasalahan dalam LAS. Sehingga dengan salah satu proses tersebut kemampuan penalaran matematis siswa dapat meningkat dan lebih berkembang. Saat guru mengarahkan pengerjaan LAS, setiap kelompok terlibat aktif dan terjadi komunikasi dua arah dengan guru. Siswa aktif mengemukakan pendapatnya dan tetap dalam pantauan dan pengarahan guru. Saat guru bertanya kepada setiap kelompok banyak yang antusias untuk menjawab termasuk keenam SP.

Berdasarkan hasil siklus 3 yang telah berhasil dilakukan dalam mencapai indikator keberhasilan maka penelitian ini yaitu upaya meningkatkan kemampuan penalaran matematis siswa model Problem Based Learning di kelas VII-1 SMPN 176 Jakarta telah dikatakan berhasil dilakukan. Sehingga kegiatan siklus selanjutnya sudah tidak perlu dilakukan.

\section{Pembahasan}

Berdasarkan hasil analisis data yang telah dipaparkan di atas maka proses pembelajaran matematika dapat dilakukan penerapannya dengan menggunakan model Problem Based Learning terlihat dapat meningkatkan kemampuan penalaran matematis siswa khususnya pada materi aritmetika kelas VII SMP. Hal tersebut terjadi karena terlihat selama pelaksanaan proses pembelajaran model Problem Based Learning, hasil nilai tes kemampuan siswa pada setiap siklus, dan hasil respons positif wawancara yang diberikan oleh guru dan siswa. Terlihat dari model Problem Based Learning yang lebih unggul dalam upaya meningkatkan kemampuan penalaran matematis siswa dibandingkan dengan model konvensional yang biasa guru terapkan selama pembelajaran sebelumnya. Pembelajaran dengan menggunakan model Problem Based Learning dapat melatih kemampuan siswa dalam berpikir logis dalam setiap penyelesaian masalah atau disebut juga melakukan penalaran matematis yang diberikan oleh model ini.

Pelaksanaan setiap tahapan dalam model ini turut membantu dalam meningkatkan penalaran matematis siswa. Hal ini terjadi karena selain dilatih secara mandiri dalam melakukan penalaran, model ini juga mendukung siswa untuk melakukan penalaran secara berkelompok sehingga dapat membuat siswa lebih mudah dalam melakukan serta mengembangkan kemampuan penalaran yang dimilikinya. Siswa juga menjadi terbiasa dalam menghadapi permasalahan karena dengan model ini dapat membuat siswa menjadi terbiasa melakukan penalaran dengan melakukan proses berpikir lebih mendalam dari biasanya. Sehingga dapat dikatakan dengan model Problem Based Learning ini dapat membuat peningkatan terhadap kemampuan penalaran matematis siswa. Akhirnya dapat terlihat dengan penggunaan model ini, siswa menjadi senang karena pelaksanaan tahap dan kemampuan siswa dalam menalar sudah terlatih dengan baik, tidak seperti pada awal-awal penerapan model ini karena siswa sudah tidak begitu merasakan kesulitan berarti. Hal ini dikarenakan penerapan model Problem Based Learning dapat mendukung, melatih dan mengembangkan kemampuan siswa dalam melakukan penalaran matematis dengan baik.

Pembelajaran matematika dengan menerapkan model Problem Based Learning dapat meningkatkan kemampuan penalaran matematis siswa kelas VII-1 SMPN 176 Jakarta pada materi aritmetika sosial. Hasil setelah dilakukan penerapan model Problem Based Learning menunjukkan terjadi peningkatan pada kemampuan penalaran matematis siswa yang terjadi pada siklus 1,2 dan 3. Hal ini terjadi sebagian besar siswa kelas VII-1 SMPN 176 Jakarta khususnya pada keenam subjek penelitian. Hal ini terlihat secara lebih jelas pada penjabaran berikut. 


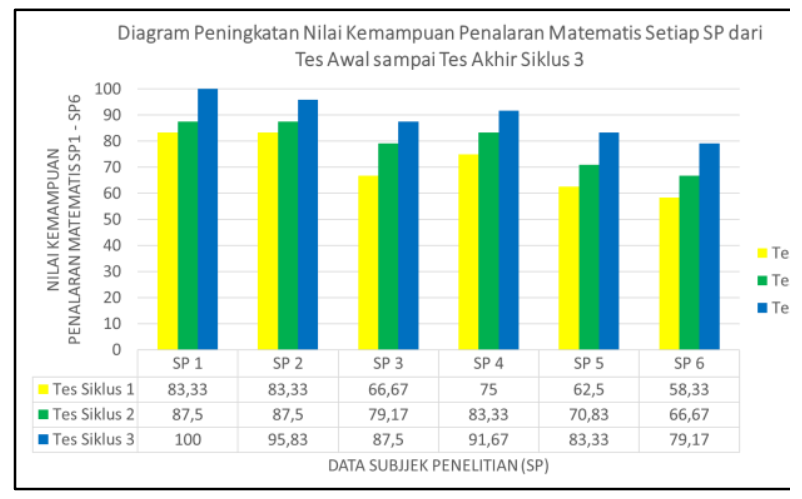

GAMBAR 3. Diagram Peningkatan Nilai Kemampuan Penalaran Matematis Setiap SP

\section{PENUTUP}

\section{Kesimpulan}

Bagian ini menjelaskan kesimpulan umum dari hasil penelitian sesuai dengan tujuan penelitian.

Berdasarkan penelitian yang telah dilakukan, maka dapat diperoleh kesimpulan bahwa:

1. Penerapan model Problem Based Learning dapat meningkatkan kemampuan penalaran matematis siswa kelas VII-1 SMPN 176 dilakukan melalui lima fase, yaitu:

a. Orientasi siswa pada masalah,

b. Mengorganisasikan siswa untuk belajar,

c. Membimbing pengalaman individual/kelompok,

d. Mengembangkan dan menyajikan hasil karya,

e. Menganalisis dan mengevaluasi proses pemecahan masalah.

2. Kemampuan penalaran matematis siswa pada materi aritmetika sosial dapat ditingkatkan dengan menerapkan model Problem Based Learning. Hal tersebut dapat dilihat dari:

a. Hasil peningkatan yang telah diraih oleh keenam Subjek Penelitian (SP).

b. Hasil perolehan nilai rata-rata tes akhir siklus kemampuan penalaran matematis siswa kelas VII-1 yaitu masuk dalam kategori "Sangat Baik" minimal 81 dapat diraih dengan nilai 84,95 pada siklus 3 .

c. Sebanyak $75 \%$ dari jumlah siswa kelas VII-1 berhasil memperoleh nilai minimal 76 berdasarkan kategori
"Baik" penalaran matematis siswa, yaitu:

i. Siklus 1: 9 siswa atau sebesar $25 \%$

ii. Siklus $2: 21$ siswa atau sebesar $58 \%$

iii. Siklus 3 : 27 siswa atau sebesar $75 \%$

\section{UCAPAN TERIMA KASIH}

Penyusunan penelitian ini tidak terlepas dari doa, arahan, bimbingan, bantuan, dan peran serta berbagai pihak. Oleh karena itu, pada kesempatan ini penulis menyampaikan terima kasih kepada:

1. Bapak Dr. Lukman El Hakim, M.Pd. selaku dosen pembimbing I dan Ibu Dwi Antari Wijayanti, M.Pd. selaku dosen pembimbing II

2. Bunda Nurakhmah, S.Pd. selaku guru matematika SMPN 176 Jakarta yang telah bersedia melaksanakan penelitian.

3. Bapak Suparjiyanto, S.Pd. selaku kepala sekolah SMPN 176 Jakarta yang telah memberikan izin melakukan penelitian, serta seluruh guru, karyawan, siswa kelas VII-1 SMPN 176 Jakarta yang telah membantu dan memberikan dukungan selama penelitian.

4. Teman-teman observerku yang telah bersedia membantu melakukan pengamatan selama penelitian berlangsung (Syifa Labiba, Anisatul Hamidah, Irma Rachmah Hidayah dan Rokhyani Nur Setiarini).

\section{REFERENSI}

Arends, R. I. (2012). Learning to teach. 9th Edition. New York: Mc Graw-Hill.

Hidayat, Sandi, Rif'at, dan Dwi Astuti. "Kemampuan Penalaran Matematis Siswa pada Materi Segitiga di Kelas VIII Sekolah Menengah Pertama." Jurnal Pendidikan dan Pembelajaran Vol.4 No.6 Hal. 1-13. 2015.

http://jurnal.untan.ac.id/index.php/jpdpb/a rticle/view/10391 (diakses Desember 20, 2018). 
Jihad, Asep, dan Abdul Haris. Evaluasi Pembelajaran. Yogyakarta: Multi Press, 2010.

Kemampuan Penalaran Matematis Siswa. Dalam Doctoral dissertation, Tesis tidak diterbitkan. Medan: PPs Unimed.

Laksono, K., \& Eko, T. Y. (2018). Penelitian Tindakan Kelas. Bandung: PT Remaja Rosdakarya.

Martiyono. (2017). Menjadi Guru Penulis: Suatu Paduan Praktis Ber-PKB, Ber-PTK, dan Menulis Artikel Ilmiah. Yogyakarta: Aswaja Pressindo.

NCTM. (2000). Principles and Standards for School Mathematics. Reston VA: NCTM.

Padmavathy, R., \& K., M. (2013). Effectiveness of problem based learning in mathematics. Dipetik Juni 24, 2018, dari International Multidisciplinary e-Journal Vol.2

Isuue https://pdfs.semanticscholar.org/1d75/162 76032eef76476b1198b63587898864fdd.p df.

Rosnawati, R. (2013). Kemampuan penalaran matematika siswa SMP Indonesia pada TIMSS 2011. Dalam F. MIPA, Prosiding Seminar Nasional Penelitian, Pendidikan dan Penerapan MIPA Vol. 18 (hal. 1-6). Yogyakarta: Universitas Negeri Yogyakarta.

Simatupang, R., \& Surya, E. (2017). Pengaruh Problem Based Learning (PBL) Terhadap

Turmudi. (2008). Landasan Filsafat dan Teori Pembelajaran Matematika Siswa dalam Pelajaran Matematika. Dalam Disertasi doktor (hal. 59). Bandung: PPS IKIP tidak dipublikasikan.

Wardhani, S. (2008). Analisis SI dan SKL Matematika SMP/Mts untuk Optimalisasi Tujuan Mata Pelajaran Matematika. Jurnal P4TK Matematika Yogyakarta, 11. 